DOI: 10.20472/IAC.2017.031.015

\author{
SUWINA CHENG \\ Lingnan University, Hong Kong
}

\title{
CHANGES IN EXECUTIVE REMUNERATION AFTER TECHNOLOGY BUBBLE
}

\begin{abstract}
:
The study examines top executive Remuneration in UK high-technology firms in an attempt to identify and understand any changes in the structure of the pay mechanism evident after the global technology market crisis at the end of the twentieth century. The results show that the relation between executive pay and market performance has weakened and that the fixed components in the pay package in those companies have increased post-crisis. These changes have likely served to compensate executives for the increased risk associated with equity-based compensation rather than to redress any perceived problems with executive incentives pre-crisis. Moreover, we also confirm a significant and negative association between executive pay and block shareholdings after the market adjustment. These findings suggest that shareholders strengthened their role of monitoring executive pay in the wake of this exogenous economic shock.
\end{abstract}

\section{Keywords:}

Corporate governance, CEO compensation, Financial crisis, High-technology firms

JEL Classification: G30, M12 